\title{
CLICK 'LIKE' AND POST IT ON YOUR WALL! CHAIN POSTS ON FACEBOOK - IDENTITY CONSTRUCTION AND VALUES
}

\section{Piret Voolaid}

\begin{abstract}
The article $^{1}$ focuses on chain posts that were collected in the years 2010-2012 and spread predominantly among girls of ten to twelve on Facebook (facebook.com) - a social network that has a membership of over 450,000 in Estonia. The source material comprising approximately 220 texts is similar by form and content to chain letters known from earlier tradition; yet, the web environment with its specific technical structure allows the texts to turn into a peculiar Facebook-like phenomenon.

The author takes a closer interest in the changes in form adapted to chain letters as a genre in Facebook environment as well as thematic categories of these letters. The analysis of the epistolary cultural phenomenon focuses on the socio-folkloric nature of texts with its communicative and socio-cultural aspects. The main focus is on how socio-cultural environment influences changes in the genre, what kind of global and local impacts occur in Estonian-language chain posts and how this everyday genre reflects the realities of the era and the values intrinsic to this age group. The levels of personal and collective identity construction of chain posters as a special age group have been analysed against the identity motivation theory known from social psychology.
\end{abstract}

Keywords: chain posts, chain letters, Facebook, identity, Internet folklore, school lore, youth lore, social networking, values, luck chain letters

\section{INTRODUCTION}

The social networking service Facebook founded in 2004 has recently gained high popularity among both younger and older Estonians, and we could well claim that this portal has become a synonym of social media. While adults appreciate, above all, the possibility of access to important information provided by this web environment, the younger generation (mainly schoolchildren) regard it primarily as an entertaining communication site and only then something related to, for example, school activities. ${ }^{2}$ Communication usually establishes certain traditions and folklore is born and spread. This article is based on a fragment of modern Internet folklore, focussing on chain messages posted in 
2010 and 2011 by a girls' community on their Facebook walls ${ }^{3}$. It is easy to disseminate a message: if you post it on the wall/timeline of your profile, it immediately shows in your friends' news feed, so that each member of the community can see the new posts on the opening page of their Facebook account, this way having a good overview of their friends' walls. So, by their nature, posts are an epistolary folklore phenomenon, a subform of the Internet memes which spreads by one click from wall to wall, forming a human chain from the posters. Similarly to a typical chain letter, a chain post constitutes a message that persuades the addressee to copy the letter and pass it on to a certain number of or as many people as possible. To a certain extent, we could regard as chain posts also passing on and sharing on the Facebook all kinds of other Internet memes (e.g. caricatures and manipulated photos, so-called demotivators). These are not included in the current research as predominantly they do not include an explicit instruction to share and forward.

This article aims to give an overview of chain letters posted on Facebook as a phenomenon spreading most actively among teenagers, to analyse the nature of folkloric posts and their material-thematic expressions and interpret the texts through identity construction and value shaping mechanisms expressed in them.

\section{THEORETICAL STARTING POINTS}

Facebook is a sub-form of new media based on information technology. Such social networks are not merely channels for forwarding information but rather structures that resemble geometrical places (in which a different life can occur) and are even adaptable to topological or abstract spaces, e.g., "I am writing on my FB homepage", "I have ... friends on the FB", etc. (Briggle 2010: 163). Information lives on this technological media ground, the user can hardly be distinguished from information and active communication as well as creation of novel knowledge is ongoing.

Any written text is born as a result of social activity (see, e.g., Kress 2004: 84-105), whereas the user chooses a suitable form for mediating knowledge. One of those distinguishable genres is Facebook chain posts. From the folkloristic point of view chain posts have a common part with chain or luck letters or luck chains known from former times. ${ }^{4}$ In Estonia, notifications about Christianorigin printed protective letters or the so-called 'letters from heaven' equipped with abundant instructions date back to as early as the end of the 18th century (Vahtramäe 1998: 181). The earliest of luck chains stored in folklore archives originates from the year 1883 (Kõiva 1993: 12), so we can speak about more than one hundred years' chain letter tradition in Estonia. In analytical treat- 
ments of local material, folklorists have pointed out historic and categorising aspects (Anderson 1937; Põldmäe 1938; Kõiva 1993), thereby also describing developments of the genre due to new technological environments (computer and Internet), approaching changes in category through, for example, the notion of dialogue (e.g. Seljamaa 2003, 2004, 2005). In an interactive environment, in which the creation and mediation of meaning is multimodal (compared to archival texts, genres are not so much linguistic categories; all kinds of audio, visual, technological and other means are considered - see Kress 2004; Torop 2008, and others), it is easier for a researcher to observe informative, social, entertainment and other roles of folkloric phenomena. By their form and content, chain posts can merge with modern urban legends, anecdotes and folkloric short forms, thereby convincingly confirming vague genre borders and adaptation of classical folkloric phenomena on the Internet (see, e.g., Kõiva \& Vesik 2009: 109). As an essential feature of modern folklore, including chain letters, researchers emphasise their ability to sensitively react to the events occurring in society and reflect them in their own way (Hoppál 1986: 62). Folklore that depends on the knowledge created by the media about current events and comments on them has also been called newslore (e.g. Frank 2011). Newslore can be expressed in many folklore forms, such as jokes (incl. catastrophe humour), urban legends, digitally altered photographs, mock news stories, press releases or interoffice memoranda, parodies of songs and poems, political and commercial advertisements, and still or animated cartoons. Facebook chain posts also acquire newslore value if they draw on real-life (tragic) events and react to both the events covered by the media and media coverages themselves. The whole net lore has to be viewed against global level, and so Estonian chain posts also demonstrate signs of close cultural exchange (incl. translations from one language to another, language merger), which accompanies increasing relative importance of distance communication nowadays.

Facebook chain posts could be called an epistolary genre, which sociologist Liz Stanley characterises as dialogical and directed to another person (Stanley 2004: 202-203). ${ }^{5}$ In Facebook environment, the chain message is not private; it can be posted on the profile or wall (in the new version also timeline) of a concrete individual; yet, it is visible also to many others. In most cases, it is oriented to an impersonal 'other'; yet, in view of a wider community. Depending on the reaction of the addressees - whether the message is copied oneto-one and passed on, or the user makes changes in it, whether the posted message is commented or the reaction is limited to reading it and clicking the 'like' button - active or passive communication is formed. As another feature, Stanley points out that letters are perspectival, their structure and content changes according to the particular recipient and the passing of time (ibid.: 
202-203). Chain posts in Facebook environment usually end in an imperative formula, e.g., "Click 'like' and post it on your wall!" or "Add to your status!", so they demand that you copy and spread the message. Thirdly, the letters have strongly developing conventions and preoccupations, and their own epistolary ethics. All these aspects can change according to particular correspondences and their temporal parameters. However, these features are not specific only of a letter as a genre, but describe social interaction on a more general level. It is complicated to subordinate the whole phenomenon to particular canons; they could rather be interpreted as an open, inter-textual, creative, dynamic context-centred phenomenon, which coincides with several genre-theoretical views of folklore (Briggs \& Bauman 1992; Bauman 1992; Ben-Amos 1997, etc.).

Researches into the youth's Internet usage indicate that their online and offline worlds are psychologically connected and new forms of technology are used for essential evolutional needs, i.e., sexuality, intimacy, increasing independence and identity quest (see Reich et al. 2012: 357). So, one of the aims of folklore spreading among the youth is to give support to satisfying such agerelated needs. In a closer analysis of the material, identity studies have been supportive, as the main starting point here is to find out how individual or collective self-concept is constructed, argued or protected through tradition (see, e.g., Kuutma 2006). During the past decade, Estonian folklorists have focused on identity issues from different angles, the most relevant keywords being, for example, ethnic identity (e.g. Korb 2012; Valk \& Ojamaa 2011), local identity (e.g. Kalda 2004), gender identity (e.g. Ehin 2003; Kalmre 2010), etc. Eda Kalmre (2010) has analysed girls' self-presentation on the example of communication portal rate.ee. Sentimental love stories are essential in girls' self-expression and identity construction, and in many ways sentimental chain letters perform the same functions. The Facebook chain posts under investigation here are chiefly the lore of a concrete age group - the active community being girls at the age of ten to twelve ${ }^{6}$ - which supports the construction of their social identity.

Social psychologist Vivian L. Vignoles (Vignoles et al. 2006: 311-312) has explained identity construction and preservation in different age groups on the basis of motivational theory. Identity construction is influenced by six main motives: self-esteem or evaluation of one's own worth, continuity or maintaining your image in different situations, distinctiveness, belonging, efficacy, and meaning, which are also related to the needs that people satisfy while constructing and perceiving their identities. This article aims at explaining whether and how the tradition of posting and commenting of chain messages is targeted at satisfying the needs related to identity construction, which motive categories (e.g. need for belonging, increasing self-esteem) are in the foreground in this tradition and how these categories are expressed through texts. 
The application of socio-psychological methods is justified in the analysis of those chain posts that refer to inter-group relations and roles and can be interpreted through the notion of social identity. According to the theory of social identity (e.g. Tajfel 1978, 1981; Valk 2003), it is the part of an individual's self-concept which is based on the knowledge about belonging to social group(s). The foundation of collective communication is the person's need for confirming and differentiating identity, on which the person's emotional self-esteem and perception of one's own worth is based. Schoolchildren's social status is assessed against the sociometric nomination method and peer nomination method (Tropp \& Saat 2010: 70). Chain posts with comments targeted at friendships can be viewed as an informal sociometric means, which is used to initiate the members of the community to make various choices (either positive, neutral or negative) and also to assess the others.

\section{MATERIAL AND ANALYSIS}

The analysis presented in this article is based on 220 text types collected by the observation of asynchronous Internet communication. ${ }^{7}$ As a Facebook user (in this research, above all, as a parent), I collected chain messages posted predominantly by pre-teens and teens or the ones posted on their walls. For social situations, I mainly acted as a passive observer; yet, sometimes also asked additional questions.

The members of the community form a semi-private forum, the access to which is afforded only to the ones registered in the environment. On average, each member has a couple of hundred friends, some of whom they have never met in real life. ${ }^{8}$ It is obvious that, in view of this, the notion of 'friend' has been expanded and modified. Teenager's self-esteem might depend on the number of friends on Facebook and this has given rise to the so-called Facebook new proverb: May you have 777 friends rather than 777 euros. The most active posters of chain letters seem to be girls at the age of ten to twelve, who obviously do not mind demonstrating their feelings and for whom the topics of chain letters (friendship, romantic feelings, family, home) and their sentimental style are essential. A similar tendency is revealed in the results of the all-Estonian school lore collection competition: among the ten-year-old schoolgirls' answers chain letters were the most numerous (see also Kõiva 1993: 13). The same themes are popular in schoolgirls' poetry notebooks and diaries, but also communication portals with large young membership in Estonia, such as rate.ee and orkut.com. The posting of chain messages features a noticeable gender aspect: although Facebook boys' community can see all the chain messages, they rarely pass them 
on. Even if they do it, they rather share ironic and parody letters, which aim at ridiculing serious and sentimental chain messages, turn them upside down and call them trash in their comments on girls' posts. Here it is important to mention that although Facebook structure favours posting both on one's own and on others' walls, this kind of chain posts are similar by their function to spam, which is forwarded without asking permission from the wall owner and which could turn out to be a deception, affecting its bona fide recipient with, for example, a computer virus of monetary damage. From a sociological point of view, spam is considered to be interesting due to the reaction that it evokes in long-term users of the Internet and computer-mediated communication. Spam is often associated with the newcomers in the virtual space, who deserve old users' resentment because they are not aware of or do not respect tacit rules (Bell et al. 2004: 165). Certain parallels can be found in posting chain letters: ten-to-twelve-year-olds are definitely more daring to forward these letters, both due to their youth (letters seem to be fresh and interesting, the topics have greater impact on them, they believe in the content more than their older peers) and ignorance about rules and customs.

\section{THEMATIC CATEGORISATION OF FACEBOOK CHAIN LETTERS}

Facebook chain posts requiring forwarding are extremely multifarious, both by the length of the texts (ranging from one sentence to longer narrations) and their topics and functions. The earlier chain letter tradition has been categorised in very different ways (e.g. VanArsdale 2007; Seljamaa 2003; Krikshchiunas 2012). In order to get a more comprehensive picture of Facebook chain letters, texts have been divided into the following categories: 1 . Friends and friendships. 2. Family and home (close relatives). 3. School and studies. 4. Chain posts following everyday events. 5. Prevention of accidents (valuation of life and health, incl. warnings against alcohol and drugs). 6. Caring about animals. 7. Chain posts related to calendar holidays. 8. Attention tasks and tests. 9. Parodies of chain letters. As is usual for folkloristic categorisations, category borders can be vague for chain posts; for example, a text about friendship can also be related to school life.

\section{Friends and friendships, search for personal and social identity}

Different chain posts can be divided into thematic rubrics. A very important facet of pre-teens and teens' lives is their peers and relations with them; diminishing of parental control over young people's activities and their social positioning 


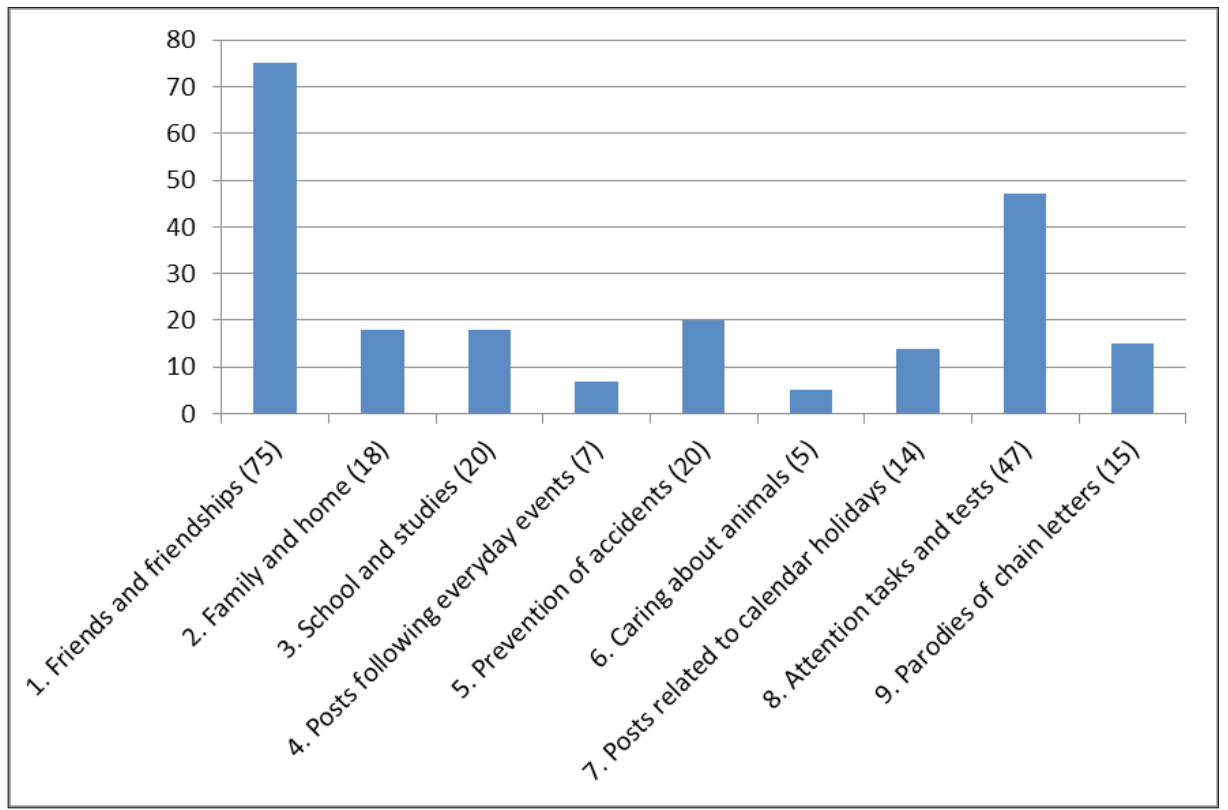

Figure 1. Thematic categories of Facebook chain letters (221 types or sets of samecontent variants).

become more important. So it is not strange that the majority of their chain posts are dedicated to friendships and relations, appealing to their peers to value real friends, testing the strength of friendship and their own position in a community. On the one hand, such texts reflect quests for social identity, featuring social relationships and belonging to social groups; they are related to mutual power relations in a lore group. This way, testing chain posts with their answers can satisfy young people's need for belonging and relating, which some researchers (e.g. Vignoles et al. 2006; Deci \& Ryan 2008: 183) regard as the primary need in self-defining theory. The need for belonging must constantly be proved by various relation contacts. On the other hand, however, they support the shaping of the youngster's personal identity (self-image or self-concept). For example, the following post enables a developing youngster to confirm his/her traits through the peers and perceive their attitudes.

Post it on your wall and get to know what other people think about you: 1. Crazy. 2. I'd like to kiss you. 3. Hyperactive. 4. Jerk. 5. I miss you. 6. Best friend. 7. Nice. 8. Smart. 9. Stupid. 10. I'd like to go on a date with you. 11. Easy. 12. Hot. 13. Funny. 14. Hugger. 15. Ravishing. 16. Pensive. 
17. Cute. 18. Beautiful. 19. Loud voice. 20. Cool. 21. I love you. You can also pick several. ;)

Self-concept comes as a reflection from the people who are significant for youngsters. It is easy for the youngsters themselves to arrange this reflection in social networking in test format, with the help of chain posts. In some of them, which operate as so-called sociometric tests, answers expected from friends are specified in percentages.

$10 \%$ - poor friend, $20 \%$ - lost contact long ago, 30\% - it's a pity we quarrelled (-), 40\% - stupid, 50\% - normal, 60\% - cool guy, 70\% - it'll be fun ;), $80 \%$ - crazy! $90 \%$ - goddamn good friend :D, 95\% - best friend ever! $97 \%$ - I like you $\odot$, , 98\% - let's go on a date?, 100\% - love you!

Copy on your wall to see what your friend picks out about you! :)

This type of chain posts are commented the most frequently, as they instigate community members to make assessments (either positive or negative) about their friends in the style: If I am the best, write $B$, if I am just a friend, write $F$, if you hate me, write $H$, if you want us to be friends forever, write $F F$. However, the texts indicate that sometimes they are constructed only in view of shaping a positive opinion; the listed qualities are either exclusively positive or the latter predominates and comments are generally approving. Sometimes, these posts are used to learn about mutual relationships; they can reveal who are leaders or who are ostracised from a social group. It is this kind of posts that support the identity construction of developing youngsters, the main motivator of which (see above: Vignoles et al. 2006) is satisfying the needs related to self-esteem, belonging and efficacy.

Facebook 'like', 'comment' and 'share' buttons enable friends to react to posts and also get feedback from the community members about concrete posts. Sentimental chain letters become a kind of medium for expressing friendly feelings towards one's peers and demonstrating caring, yet also for ousting some members from the group. Quite a few posts dwell upon boys' and girls' sentimental feelings and love, which is ineluctable in teenagers' generic selfdetermination and maturation processes. Topics could be unravelled in long and tragic love stories, like, for instance, the following post:

What is the true meaning of love?

A girl and a boy are motorcycling at $160 \mathrm{~km} / \mathrm{h}$. Girl: Please brake, I am scared. Boy: No, this is fun! Girl: No, it's not. Please, we are going too fast! Boy: OK. Tell me you love me and I will slow down. Girl: Okay. I love you. Could you brake now, please ... Boy: Now give me a hug. *The girl hugs the boy.* Boy: Could you take my helmet off and put it on yourself? 
It's driving me nuts. Next day in newspapers: A motorcyclist ran into a building due to a brake problem; the driver was killed, the passenger survived. What really happened was that the boy understood half-way that the brakes were out of order, and instead of telling the girl about it, he asked her to tell him she loved him and felt her hug for the last time ... The boy gave his helmet to the girl in spite of the fact that it meant his own death ... $\vee \vee$ If you love someone, post it on your wall.

This kind of urban legends with nameless characters spread widely in chain posts. The unexpected punch line is emotionally easy to remember and has an educational connotation.

Novel chain posts comprise a number of texts in the form of a questionnaire, which are not anonymous any more but involve concrete members of the community. Many of them are intriguing and simulate the forbidden/hidden world of alcohol, sex and other topics, in which the posters at this age have no practical experience yet, although they certainly pursue interest in the socalled adult issues.

Birthday! Go to your profile and take the first eight friends on the left:

Birthday child: ...

Drops 'dead' under the table: ...

Jumps into the cake: ...

Tanks up with vodka: ...

Performs a striptease on the table: ...

Dances by him/herself: ...

Kisses the birthday child: ...

Comes to the party uninvited and gets drunk: ...

Congratulations! :D

This kind of birthday questionnaire enables youngsters in their pre-teens to develop their fantasy world and feel out boundaries. The described party culture could be a reality for adults, yet provides youngsters a creative opportunity to peep into the adults' mysterious activities. Irrefutably, these topics are largely influenced by modern media and television.

The lore of postmodern era is closely connected with popular culture. The impact of popular culture, advertising and media on youngsters' world, including interest in films, music and sports, is confirmed by the presence of local and foreign youth idols anchored in posts (e.g. Justin Bieber, Rihanna, famous Estonian pop singers Koit Toome, Getter Jaani, etc.), characters from Harry Potter stories and things related to them, etc. 
Go to your profile and look to the left; these ten friends are:

Lady Gaga: ... :D

Michael Jackson: ... :D

Madonna: ... :P

Selena Gomez: ...

Rebecca Black: ... :P

Miley Cyrus: ... xD

Justin Bieber: ... x)x)

Usher: ... :D

Rihanna: ... :P

Bruno Mars: ... :D

Posts are mainly commented on by the members of the community whose names happened to be in the list. The things happening, for example, at a birthday party can be intriguing, comments are usually humorous and allow for fantasies on the basis of activities or characters in the post, refute a concrete action or exaggerate it and continue fantasising.

\section{Close relatives (family and home)}

A separate sub-topic is related to family members and home, which proves that family, i.e. parents, grandparents and other close relatives (e.g. sister, brother) are important in young people's lives. These posts indicate that youngsters care about their mothers and fathers and these chain letters are typically posted in waves on Mother's and Father's Day but also at other times. Chain posts relating to family members confirm the results of several researches (e.g. Harter 1999), which claim that in the teens, peers' opinions become more and more weighty, whereas parents and next of kin are still regarded as significant and remain so. ${ }^{9}$

Sometimes the posts speak (either directly or indirectly) about parents' failure to do something and admonish them to make choices in the interests of their children and appreciate moral values. This idea is well expressed in the following allegoric narrative, in which the son is trying to give a hint to his father that time dedicated to the child should be more important than work.

Father came home from work late at night. He was tired and grumpy as always. His five-year-old son was waiting for him at the doorstep.

"Dad, could I ask you something?"

"Of course, what's up?"

"Dad, how much do you make an hour?" 
"What do you need to know that for?" the father got upset.

"I need to. Please tell me how much you make an hour."

"Well, around five hundred. Why?"

"Dad, could you lend me three hundred kroons?"

"You want money for a silly toy, don't you?" Father raised his voice. "Go

to your room and go to bed! You can't be such an egoist! I work the whole day long, come home dog-tired, and you are putting forward demands!"

The son went quietly into his room and closed the door. The father was still grumpy. "First he asks about my salary and then he wants money!" After a while he calmed down and started feeling sorry for the boy. "Maybe he really needs something so badly? Oh, what the heck! He has never asked me for money before!"

When the father went to his son's room, the latter was already in bed. "Are you asleep already?" the father asked.

"No, I am just lying," the boy answered.

"I was too tough with you. I had a hard day today. I am sorry! Here's the money."

The boy thanked his father cheerfully and took several worn-out banknotes from under his pillow. When the father saw that his son already had money, he felt spiteful again. The boy carefully counted all the money.

"Why did you ask me for money if you already had some?" the father grumbled.

"I needed some more but now I've got enough," the son answered. "See, here's exactly five hundred kroons. I would like to buy an hour of your time. Please come home an hour earlier tomorrow and let's have dinner together."

If you value most the time that we spend with our loved ones, click 'like' and post the parable on your wall!

Seemingly minor details refer to cultural and social changes, so the monetary unit 'kroon' enables us to date the parable back to the period of Estonia's own money, which ended on December 31, 2010.

Posts under this category feature caring, kindness and honesty; in addition to mother and father other close relatives are also in the foreground; the following post, for example, expresses love for brothers and sisters:

My friend asked me if I love my brother/sister. I answered in the negative. Then he asked if I would help them if they had a problem; I said no. Finally he asked if I cared about my brother/sister at all. I answered: "I don't love my brother/sister, I adore them; if they had a problem, I wouldn't just help them but would run for them into a burning house, 
and if they weren't there any more, I would die." Click 'like' and put it on your wall if you have the best brother/sister in the world! :)

I have differentiated between the first and the second categories, although they both feature a moral expressing the importance of friendship and altruism, which allows viewing them also as a joint category (about abstract altruism and temporality of human life as different categories see, e.g., Seljamaa 2003).

\section{School and school-related events}

To some extent, the third topic relates to the first one, yet, has more to do with school and things happening there. These messages feature positive facets related to school, which find their expression in school anticipation and attitude towards school and peers as something pleasant, for example:

I like my class very much. If you like yours, too, and you would like to see it, click 'like' and post it on your wall (L).

On the other hand, these messages reflect, through a humorous prism, some haunting obligations accompanying school and learning:

Why do you have to go to school? Math - we have calculators, right? Mother tongue - I can speak, can't I? Physics/chemistry - yeah, sure, the sun is hot! Biology - well I definitely know that hares have ears. Health education - I know how to walk and run if necessary. Geography - north, east, south, west. History - I know exactly what happened yesterday. Post it on your wall if you think the same! (:

The group under study comprises youngsters in their pre-teens, yet chain letters are also posted by adults. It was namely them who, on the first days of September, 2012, initiated a chain appeal relating to the beginning of the school year, which testifies to the educational opportunities provided by this folklore genre. Adults and parents are in contact with children through Facebook community and in this concrete case chain posts are used for educational purposes, to remind the youngsters about rules of behaviour.

To all the youngsters who return to school!

If you see that somebody has a hard time making friends or you witness someone being harassed because they do not have friends or they are too shy or not wearing the finest clothes, please be there for them. Say hello or at least smile when you meet them in the corridor or schoolyard. You 
do not know what their life outside school is like. Your being friendly can change someone's life a lot!

Copy this on your wall to abolish bullying at school.

On a more general plane, this posting about school harassment refers to shaping common values, and a comment by an adult following it (e.g.: This is important and is also valid for teachers and in adults' working places) provides a wider social meaning, also indicating that bullying and power abuse are issues not only at school and for schoolchildren but also spread in society on a wider scale. The authorship of these texts is a separate topic: when reading the posts, it seems that the educational and more complex parables are created by adults who are originators of directional values and whose texts are consumed by youngsters.

\section{Chain posts spreading as news(folk)lore}

In order to understand the background of some chain posts, we have to ask what exactly was taking place in society when a concrete letter spread or which events were in the centre of media or public attention at the time. In quite a few cases, posts have been initiated by real situations, topical events and convulsions and their media coverage. Chain letters may reflect emotions and fears relating to the surrounding reality and instigated by concrete events. So, for example, chain posts reveal human horror and concern about the bloodshed on Utøya Island in Norway in July 2011 and the impunity of the criminal responsible for it.

The person who killed at least 92 people in Oslo can be sentenced for 21 years at the most. Put it on your wall if you think that he deserves life sentence or capital punishment.

Information about events is usually obtained through the media, whereas chain posts are a reaction to both the events and their media coverage. Through media world and distant events as well as local specific ones reach the youngsters. Involvement in social bottlenecks can be demonstrated by the post spread as newslore in the autumn of 2011, which appeared after an accident in a nursery school in Tallinn, and which appealed to the city authorities to think about children's safety and fix the playgrounds.

Yesterday at 12 an innocent three-year-old boy got killed in a nursery school in Lasnamäe (district in Tallinn)!!! The thing that caused it was a ladder with a missing rung. The boy got stuck in between the rungs and suffocated. The paramedics tried to resuscitate him but failed. Why 
couldn't the city authorities fix the playgrounds at nursery schools? Why are politicians interested only in their pay rise? Why couldn't they spend this money on children's playgrounds? If you agree that the city should fix the playgrounds at nursery schools, click 'like' and post this message on your wall. ://

Such chain narratives often comprise stereotypes (e.g., politicians are only interested in their own pay rise) through which more general collective identities are assumed and processed.

\section{Prevention of accidents (incl. computer viruses, alcohol, drug- related)}

Sometimes chain posts feature a threatening tone, which in itself can frighten people. This is actually a classical characteristic of the chain letter: the forwarder of the letter is promised good luck whereas the one breaking the chain is threatened with bad luck and consequences in the style: if you do not copy the posting and pass it on within a certain time, something very bad will happen to you. The spread of the religion-shaded 'letters from heaven' started to subside already after the First World War (see, e.g., Anderson 1937: 23); yet, the exploitation of superstition and magic inherent in these letters (belief that if you act in a certain way and pass on the letter, you can control your life and guarantee success) is there even nowadays. Short quizzes testify to the fact that it is namely younger posters that believe in the content of these letters. ${ }^{10}$ Yet, nowadays, the role of letters in communication is more important than in the past, especially as technical solutions enable us to comment on the letters and express our own opinions about them.

This material also includes serious warnings. Chain letters are used, for example, to inform the peers about computer viruses, although we cannot be sure whether or to what extent the users have actually come across these viruses themselves.

There is a trojan virus called Koobface worm that targets Facebook users. It gathers your information, penetrates the system and closes it down. Don't open the link Barack Obama Clinton Skandal. And if Smartgirl 15 sends you a friend invitation, don't accept it, as it is a VIRUS. If any of your friends should accept it, you will also get this virus. PUT THIS ON YOUR WALL AND SPREAD AMONG YOUR FRIENDS!!!!!

Bad habits are also recalled; for example, young people are warned against sitting behind the wheel after consuming alcohol and suggested they should 
also impede their peers from doing it. The plots of warning chain letters might be loans from urban legends of earlier times. Such longer and often moralising parables are rather like practical warnings and precautions, reminding young people of the things that they might forget in their bravado. The following post is a regretful address to the mother by a girl who was killed in a car accident due to alcohol. The aim of this extremely emotional writing with moral shading is to make youngsters ponder on this and warn about the consequences.

Mom, I went to a party with my friends and I remember you telling me, "Don't drink!" You asked me not to, as I was supposed to drive after the party. So I only had soda. I was proud of myself as I followed your advice. Contrary to my friends, I made the right choice.

When the party was over, everybody got in the car, although they shouldn't have driven. I knew that I was sober. Mom, I couldn't image what the future had in store for me ... Now I am lying on the asphalt and can hear policemen talking ... There is blood all over the asphalt and I am trying not to cry ... I can hear the doctors say I am not going to make it ... I am sure that the friend who was driving didn't think he was going that fast. After all, he had decided to drink and now I must die. Why do they do it, Mom?!?! Although they know they destroy lives.

I am in such pain - as if I have been stabbed with several knives.

Please tell my sister not to be scared, and my dad to be strong. Someone should have told my friend not to drink if he was going to drive. If his parents had warned him like you did with me, I would still be alive. My breathing gets weaker and weaker and I am so scared, Mom. These are my last moments and I am so desperate! I'd like to hug you and tell you how much I love you ... I love you, Mom ... Goodbye ...

This was written by a journalist who happened to be on the place of accident.

The girl whispered these words before she died, and the shocked journalist wrote them down. The same journalist started a campaign against drunk driving. If you read this post but do not share it or even delete it, you will lose your chance; even if you don't drink yourself and it doesn't concern you directly, you'll make others realise that their life is in danger ...

Please copy it and post it on your wall!

Digital folklore researcher Trevor J. Blank has emphasised that "while orally transmitted legends convey societal fears and prejudices in coded language, electronically transmitted narratives express these sentiments more abrasively, due to the sender's anonymity" (2009: 9). Nowadays, people face traffic-related 
fears from the early childhood, and traffic accidents caused by drunk driving as well as the topic of death is everyday reality in the media, which also reaches young people's information field. Sharing of (anonymous) letters warning against, e.g., pedophiles, thieves and swindlers can become so extensive in social media that it makes people unnecessarily concerned and panicky about their own and their loved ones' safety (see, e.g., Jaagant 2013). As an example of a concrete panic campaign, we could mention here the warning shared on Facebook in February 2013 about a man who was said to have coaxed a child standing at the bus-stop near a school in the vicinity of Tallinn into coming into his car; this fact was also thoroughly investigated by the police (Jaagant 2013). The spread of serious warning letters can be supported and intensified like a gossip by some real (tragic) events. In March 2012, the Estonian public was shocked by the murder of a nine-year-old girl Varvara in Narva. As even today, a year after the murder, the police is still clueless as to who did it, the circulation of this kind of warnings among adults (parents) as well as youngsters themselves is quite understandable and motivated. In comparison to the posts of the previous subgroup, the concrete event is not mentioned in plain language; yet, it hovers in the background. The essence of social media and the form of chain posts along with commenting possibilities fits perfectly for channelling fears; yet, it can reach far beyond the event itself and, due to narrative variations and exaggerations, create panic among community members.

\section{Caring about animals}

Relationships between animals and people in modern society are handled in animal-related posts, which urge compassion towards the weaker ones (e.g. sick or homeless animals) and appeal to people to take empathic action. Many (city) children have pets; the concurrent great responsibility is emphasised, for example, in the posting made up of animal images from ASCII-symbols.

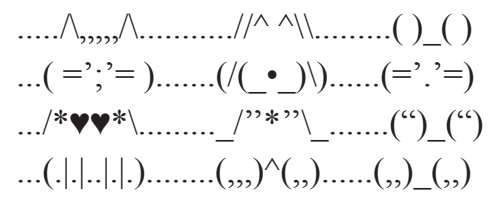

Click 'like' and post it on your wall if you never throw out pets and care about them!

ASCII or symbol art consists of pictures pieced together from printable characters and is often found in Facebook chain letters. 
Sometimes the letters consist of narratives and statements that are similar to urban legends and horror stories and imply believing, yet are apparently not very truthful. The following is a sample text that describes as a truthful tradition the way that cats are treated in China - a faraway area both geographically and culturally, intensifying an ethnocentric stereotype.

A: It is allowed to kill animals in China! Women come and film how they kill kitties! First they beat the kitty and then take their high-heeled shoes and cast them against the kitty's head and belly. The kitty cries but the women laugh! And then it doesn't suffer anymore and dies! I can't understand what's wrong with these people!!! :( If you share my opinion, click 'like' and post it on your wall!!!

B: Horrible.

A: :(

C: Creepy and absolutely unacceptable! :( I wonder if the Chinese cannot help it?! : (The animal is absolutely helpless against humans and I think it is just hideous and heartless to take advantage of it this way! :( What do they get out of it?! :( I am not going to copy it on my wall because (I don't mean any harm with it) it makes me sick and I feel like weeping, but I wish with all my heart this would end and this is not only the Chinese who do such things! :(

A: YES... I agree.

D: And this should be disallowed to EVERYBODY!

D: But it is nice that Estonians still primarily wear their high-heeled shoes instead of using them for 'a bit' different purpose...

A: :D

E: But why can't we punish the people who mistreat animals? We punish the ones who abuse other people, don't we?

D: Indeed.

The four girls' discussion following the post is especially interesting. All the commenters agree that the way animals are treated must be disapproved ( $\mathrm{hid}$ eous, unacceptable, makes me sick), and they offer solutions (punishment) or even find something positive (it is nice that Estonians still primarily wear their high-heeled shoes). The commented chain posting is a step forward from the traditional pedagogical system based on orders and prohibitions and allows for shaping common values in discussion. 


\section{Attention questions and tests}

One of the categories of chain posts is attention questions and different (arithmetic, optical, etc.) tests, which create positive emotions and also test your mental abilities (smartness and intelligence), or are simply meant for entertainment and fun. Their purpose is similar to other dialogical questionanswer folkloric forms, like, for example, riddles in their variety (classical riddles, conundrums, droodles, etc.). Some of them require an answer, others are rather like anecdotes - the answer follows the question and forms a surprising punch line provoking laughter.

You are really smart if you understand this message.

TH15 M355AG3 53RV35 TO PR0V3 HOW OUR M1ND5 C4N DO 4M4Z1NG TH1NG5! 1MPR3551V3 TH1NG5! 1N TH5 B3G1NN1NG 1T WA5 H4RD BUT NOW, ON TH15 L1N3 YOUR M1ND 15 R34D1NG 1T 4UT0M4T1C4LLY W1TH OUT 3V3N TH1NK1NG 4B0UT 1T, B3 PR0UD! 0NLY C3RT41N P30PL3 C4N R34D TH15 F1R5T T1M3!

Click 'like' if you understood the message, and post it on your wall ;D (NB! Don't lie). As I posted it on my wall, it means that I am good at this kind of things. :-

\section{Chain posts related to calendar holidays}

Holiday greetings in the form of chain posts remind us of the coming holiday and expectations related to it.

Popular chain posts in this category are the ones representing ASCII art known from earlier e-chain letters, e-congratulations, etc. ASCII-symbols can illustrate messages posted on different topics; yet, the most frequent ones are Christmas trees, candles or snowflakes made up of characters and symbols typical of Christmas-time postings.

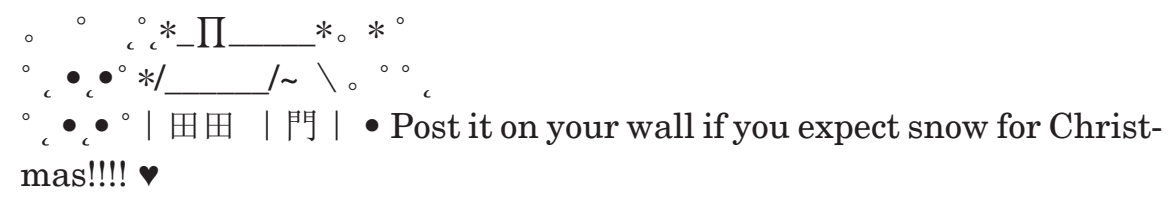




\section{Parodies of chain letters}

A separate category comprises jokes about Facebook, from sayings to anecdotes. These include aphorisms and maxims from earlier times posted on Facebook walls. Defining interpretations about school and life in general seem to be appropriate for spreading as a new wave of chain letters in social media.

A great number of chain posts are parodies of chain letters, which emphasise that this phenomenon should not be taken very seriously and could rather be treated as useless spam. Even in mainly comic parody texts the final formula is an order to spread the text and the interrupter of the chain is threatened to be punished; yet, the hyperbolic images and exaggerated ideas make you doubt their plausibility.

Copy it on your wall if chain letters get on your nerves; for example: if you don't share it, a faceless man will come and strangle you ... FB IS NOT REAL LIFE!

In contrast, some parodies demolish the style of the chain letter. The following list of punishments inflicted on the posters of chain letters is a specimen of absurd humour:

Each time you copy some kind of sentimental crap on your wall:

* an angel dies of cancer;

* one little penguin gets its feet cut off;

* one dolphin also dies each time, a very cute one;

* at least ten kittens are castrated;

* five dolphin pups get killed with an oar;

* two pandas are cut into shashlik meat;

* at least one person in your friends list thinks you are an idiot.

Attitude towards earnest chain posters is expressed, for example, in the following post: "If you have always been an idiot who shares all kinds of crap on your wall, add it in your status".

Some parodies with their metaphors appear like philosophic contemplations, which, analogously with aphorisms and defining sayings should instigate further and more serious reflection.

Facebook is a mental institution and we are all patients here. We are sitting alone, staring at the screen, imagining that we are being social. Some of us have fantasy farms, -towns, -animals and other things. We nudge one another and think it is okay, and we even write on the walls. If you are also being treated here, scribble it on your wall! I stole this message from another patient! :D 
On the basis of a sample story, a parody can also state in plain words that nothing will happen to the chain breaker.

A girl was on Facebook in her computer. She saw a letter, saying: "If you don't share it, you will die tomorrow!" The girl did not copy it on her wall and guess what? NOTHING HAPPENED! Share it if you hate these chain letters!!

It is mainly chain letters that are ridiculed; yet, sometimes chain postings are also used to mock at other genres. For example, understanding of the following chain message entitled Pen is a Writing Implement needs concrete background knowledge:

Hi kid!

Are you one of those who don't carry a pen? Well ... borrow from others? What?? This is your decision, I wouldn't borrow my pen to any of the 'new pupils'; why should you? The pen is really and actually the only implement that a child uses for writing. Do you know how big is the percentage of Estonian children that carry a pen? I don't, but what is wrong with you? If somebody speaks about pens, remember and hammer it into your head and write it on your wall that A PEN IS A WRITING IMPLEMENT!!

This is obviously a ridiculing imitation of the HIV prevention campaign organised by the National Institute for Health Development in the autumn of 2011 under the heading Condom is Sex, which evoked wide response in the media and among the general public, giving rise to a number of textual and video parodies. The Facebook chain letter version is a good example of these parodies.

The majority of chain posts are international and are translations of mainly English-language wall posts. Only in a few cases I have found chain posts in English among the ones posted by Estonian youngsters; most of them spread in Estonian and are sometimes supplemented locally. As in their search for ethnic identity youngsters are open to cultural and linguistic influences (Tammemägi \& Ehala 2012: 243), the spread of translated texts in the mother tongue as written everyday tradition is useful for the sustainability of the language (although a teenager can understand the texts also in English and could just as well keep and share the original version). However, we have to agree that the translations of the chain posts are often clumsy and crude. English-language computer terminology has brought into Estonian such direct loans from English as, e.g., kopi (copy) and peist (paste), whereas Facebook technical system requires the usage of such words as laik (like) and šeer (share). 


\section{IN CONCLUSION}

There is nothing new under the sun! The tradition of chain letters has been transferred, with alterations, from the past to the present. Many formal elements and content motives can be found in earlier folkloric records, and their origin can be traced back to the religion-shaded 'letters from heaven' (allegedly written down by God or Jesus Christ), poetry notebook tradition or well-known children's horror stories, but also different jokes and folkloric short forms. However, chain posts, even if they apply topics, structural canons, etc. known from earlier tradition, leave the impression of a fresh tradition in the pre-set Facebook environment and should be treated in close connection with wider cultural context. In web environment they could be viewed as spam; yet, undoubtedly, they constitute a peculiar form of everyday communication, which, due to their evergreen topics as well as reminders of current events can provide significant information about the era, environment, culture and worldview on a wider scale. Chain messages are part of the young poster's daily spontaneous person brand or public image and reveal certain things about the whole lore group who share these letters, sometimes change them at their own discretion, post them on their walls, comment on them and thereby constantly communicate. By their nature chain posts support pre-teens' identity construction mechanisms, and the topics (friendship, romantic feelings, home, family, close relatives, pets, shocking public events concerning young people, etc.) support individual self-quests and evolution of social skills. These letters also represent spheres of collective identity. In identity construction, different factors relating to satisfying youngsters' self-esteem, continuity, distinctiveness, belonging, efficacy and meaning operate as motivators.

A more detailed analysis of chain epistolarium indicates that these texts often present values essential and meaningful from the point of view of the existence of Man as a social being. These could refer to caring, honesty, justice, preservation of life and health both by youngsters' family members and peers at school as well as virtual and real-world communities, and also attitudes towards worldwide problems. Recently, children's and youngsters' value education and systematic shaping of values have been widely discussed in Estonia. From the point of view of the researcher, chain posts operate as indicators for young people's values; also, through these postings informal - everyday and organic, unnoticeable and natural, created and regulated by young people themselves - value education takes place, which shapes moral concepts in accordance with the ideas widely spread in society, yet often questioning them. 
Modern folklore is open to rapid changes, short-termed as to its content and loses its topicality quickly. We dare not predict how viable the phenomenon of chain posting will be and what kinds of developments it will be undergoing. Yet, it is evident that Facebook with all its opportunities seems to be a suitable place for this rapidly modifying folkloric phenomenon.

\section{NOTES}

1 Research for this article was supported by research project SF 0030181s08 and grants ETF 8149 and ETF 8137.

${ }^{2}$ Young people often spend their out-of-school time at the computer. According to 2007 school lore collection competition, schoolchildren use the computer two to four hours per day on average, mainly visiting communication portals, the most popular of which in 2007 were rate.ee, feim.ee and orkut.com (Voolaid et al. 2007: 358). The peak of Facebook among Estonian users was the year 2010.

3 In 2012, Facebook took into use, instead of the wall, the timeline application, with an aim to turn the user profile into a virtual notebook.

4 Synonymous terms chain letter, luck letter and luck chain, which most probably are German loans in Estonian, have been discussed by folklorist Mare Kõiva (1993: 12), and in more detail by Elo-Hanna Seljamaa in her bachelor's thesis (2004: 11), which mentions as the core of chain letters or classical chain letters the ones exploiting good or bad luck. In this article the terms chain letter (with a wider meaning) and chain post (more accurate in Facebook environment) are synonyms of equal meaning, their sub-form being luck letter or luck chain.

5 Here it is essential to point out that the idea of a dialogue (according to Mikhail Bakhtin) on an extensive meaning field has been used by Elo-Hanna Seljamaa (2004) in her in-depth research into chain letters as a dynamic folklore genre, which highlights, above all, the researcher's dialogue with empiricism but also relationships with other researches.

6 The Children's Online Privacy Protection Act (COPPA) mandates that websites that collect information about users (like Facebook) are not allowed to sign on anyone under the age of thirteen. Accordingly, Facebook's Statement of Rights and Responsibilities requires users of the social network to be at least thirteen years old. In Estonia as in many other countries many pre-teens use the service anyway: some get permission to create an account from their parents while others lie about their age to get past sign-up restrictions.

7 The original chain posts are in the possession of the author; the majority of the text corpus has been published in a popular-scientific collection "Pane like ja postita oma seinale: Valimik Facebooki ahelpostitusi" (Click 'like' and post it on your wall: Collection of Facebook Chain Posts) (Voolaid 2012). 
8 School lore fieldwork in Hiiumaa in October 2012 showed that friends most active in virtual communication on Facebook are largely the same ones with whom everyday eye-to-eye communication occurs (e.g. class- and school peers).

9 This assumption was also confirmed by the results of the all-Estonian school lore collection competition in 2007. The first topic in the questionnaire entitled Leisure and Friends asked the pupils to name someone they wanted to follow. In addition to favourite musicians, actors, singers and sportsmen, youngsters often mentioned their parents, which shows how important they consider their family (see also Voolaid et al. 2007: 356).

${ }^{10}$ In October 2012, I participated in school lore fieldwork in Hiiumaa. In oral interviews, I also asked questions about chain postings. In several cases teenagers from basic school answered in retrospective that several years ago they had passed on these letters as they believed in the threats befalling on those ignoring the orders. They also emphasised that now, being older and more experienced, they did not believe in it any more.

\section{REFERENCES}

Anderson, Walter 1937. Kettenbriefe in Estland. Eesti Rahvaluule Arhiivi Toimetused 7. Tartu: K. Mattiesen.

Bauman, Richard 1992. Genre. In: Richard Bauman (ed.) Folklore, Cultural Performances, and Popular Entertainments: A Communications-centered Handbook. New York: Oxford University Press, pp. 53-59.

Bell, David \& Loader, Brian D. \& Pleace, Nicholas \& Schuler, Douglas 2004. Cyberculture: The Key Concepts. London \& New York: Routledge Taylor \& Francis Group.

Ben-Amos, Dan 1997. Genre. In: Thomas A. Green (ed.) Folklore. An Encyclopedia of Beliefs, Customs, Tales, Music and Art, Vol. II. Santa Barbara, California: ABCClio, pp. 409-415.

Blank, Trevor J. 2009. Folklore and the Internet: Vernacular Expression in a Digital World. All USU Press Publications, Book 35. Utah: Utah State University Press. Available at http://digitalcommons.usu.edu/usupress_pubs/35, last accessed on January 23, 2013.

Briggle Adam 2010. Dear Facebook. In: D. E. Wittkower (ed.) facebook and Philosophy: What's on your mind? Popular Culture and Philosophy, Vol. 50. Chicago and La Salle, Illinois: Open Court, pp. 161-171.

Briggs, Charles L. \& Bauman, Richard 1992. Genre, Intertextuality, and Social Power. Journal of Linguistic Anthropology 2 (2), pp. 131-172, doi: 10.1525/ jlin.1992.2.2.131.

Deci, Edward L. \& Ryan, Richard M. 2008. Self-Determination Theory: A Macrotheory of Human Motivation, Development, and Health. Canadian Psychology, Vol. 49, No. 3, pp. 182-185. Available at http://www.psicologia-uniroma4.it/LS/organizzazione/materiale/cap-49-3-182[1].pdf, last accessed on January 24, 2013, doi: 10.1037/a0012801. 
Ehin, Kristiina 2003. Naiste identiteedi muutus pärast Esimest maailmasõda - rahvalaul kõneleb. [Women's Identity Change after World War I - Folksong Speaks.] Pärimus ja tõlgendus: Artikleid folkloristika ja etnoloogia teooria, meetodite ning uurimispraktika alalt. [Tradition and Interpretation. Articles on Theory, Methods and Research Practice in Folkloristics and Ethnology.] Tartu: Tartu Ülikooli Kirjastus, pp. 158-172.

Frank, Russell 2011. Newslore: Contemporary Folklore on the Internet. Jackson: University Press of Mississippi.

Harter, Susan 1999. The Construction of the Self: A Developmental Perspective. New York: The Guilford Press.

Hoppál, Mihaly 1986. Chain Letters: Contemporary Folklore and the Chain of Tradition. In: Irma-Riitta Järvinen (ed.) Contemporary Folklore and Culture Change. Suomalaisen Kirjallisuuden Seuran Toimituksia 431, Helsinki: Suomalaisen Kirjallisuuden Seura, pp. 62-80.

Jaagant, Urmas 2012. Häda sotsiaalmeedias: eestlane läheb alusetu hoiatuse peale paanikasse. [Problem in Social Media: Estonian Panics over a Groundless Warning.] Eesti Päevaleht (newspaper), March 5. Available at http://www.epl.ee/news/ eesti/taismahus-hada-sotsiaalmeedias-eestlane-laheb-alusetu-hoiatuse-pealepaanikasse.d?id=65773262, last accessed on March 20, 2013.

Kalda, Mare 2004. Siinpool jõge - sealpool jõge. Mõne Emajõe-äärse koha loost. [This Side of River - That Side of River. Stories of Places at River Emajõgi.] Mäetagused, Vol. 27, pp. 73-104. Available at http://www.folklore.ee/Tagused/nr27/kalda.htm, last accessed on January 23, 2013.

Kalmre, Eda 2010. Tüdrukute materjalikogudest ja eneseesitlusest internetis rate.ee päevikute armastusjutustuste näitel. [Girls' Collections and Self-Presentation Online on the Example of Love Stories in rate.ee.] In: Eda Kalmre (ed.) Tulnukad ja internetilapsed. Uurimusi laste- ja noortekultuurist. [Aliens and Children of Internet. Studies about Contemporary Children and Youth Culture.] Tänapäeva folkloorist 8, pp. 215-245.

Kõiva, Mare 1993. Õnnel pole hinda. [Luck is Priceless.] Koolipärimus. Shkol'nyi fol'klor. Pro folkloristika I, pp. 12-15. Available at http://www.folklore.ee/era/nt/PF1/, last accessed on April 3, 2013.

Kõiva, Mare \& Vesik, Liisa 2009. Contemporary Folklore, Internet and Communities at the beginning of the 21st Century. Media \& Folklore: Contemporary Folklore IV, pp. 97-117.

Korb, Anu 2012. Siberi eestlaste kohanemisest ja sulandumisest pärimusainese põhjal. [On the Adaptation and Acculturation of Estonians in Siberia on the Basis of Folklore Material.] Mäetagused: Hüperajakiri, Vol. 50, pp. 47-70. Available at http://www.folklore.ee/tagused/nr50/korb.pdf, last accessed on January 23, 2013.

Kress, Gunther 2004 (2nd ed.). Literacy in the New Media Age. London \& New York: Routledge, http://dx.doi.org/10.4324/9780203164754.

Krikshchiunas, Povilas 2012. Elektronnye pis'ma po tsepi: k voprosu o transformatsii zhanra. [Electronic Chain Letters: To the Issue of Genre Transformation.] Nauchnyi al'manakh: Traditsionnaia kul'tura 3 (47), pp. 152-162.

Kuutma, Kristin 2005-2006. Identiteet. [Identity.] In: Tiiu Jaago (ed.) Argikultuuri uurimise terminoloogia e-sõnastik. [Electronic Glossary of Everyday Culture 
Terminology.] Tartu Ülikool, eesti ja võrdleva rahvaluule osakond. Available at http://argikultuur.ut.ee, last accessed on January 23, 2013.

Põldmäe, Rudolf 1938. Üks haruldane tüüp eestikeelseist taevakirjadest. [A Rare Type of Estonian Letters from Heaven.] Õpetatud Eesti Seltsi Toimetused XXX, pp. 529-537.

Reich, Stephanie M. \& Subrahmanyam, Kaveri \& Espinoza, Guadalupe 2012. Friending, IMing, and Hanging Out Face-to-Face: Overlap in Adolescents' Online and Offline Social Networks. Developmental Psychology, Vol. 48 (2), pp. 356-368, doi: 10.1037/a0026980.

Seljamaa, Elo-Hanna 2003. Kettkirjade traditsiooni muutumisest. Taevakirjadest elektronkettkirjadeni. [About Changing the Tradition of Chain Letters. From Letters from Heaven to Electronic Chain Letters.] Teekond: Pro Folkloristica X, pp. 171-183.

Seljamaa, Elo-Hanna 2004. Dialoogis kettkirjadest. [Dialogical Chain Letters.] Bachelor's thesis. Manuscript at the Department of Estonian and Comparative Folklore, University of Tartu. Seljamaa, Elo-Hanna 2005. Kettkirjadest folkloristikat ja folkloriste otsimas. [Looking for Folkloristics and Folklorists in Chain Letters.] Pro Folkloristica XII, pp. 139-150.

Stanley, Liz 2004. The Epistolarium: On Theorizing Letters and Correspondences. Auto/ Biography 12 (3), pp. 201-235, http://dx.doi.org/10.1191/0967550704ab014oa.

Tajfel, Henri 1978. Differentiation between social groups: Studies in the social psychology of intergroup relations. London: Academic Press.

Tajfel, Henri 1981. Human Groups and Social Categories. Cambridge: Cambridge University Press.

Tammemägi, Anni \& Ehala, Martin 2012. Koolinoorte keelehoiakud 2011. aastal. [Language Attitudes of Estonian Schoolchildren in 2011.] Keel ja Kirjandus, Vol. 4, pp. 241-260.

Torop, Peeter 2008. Multimeedialisus. [Multimediality.] Keel ja Kirjandus, No. 8, pp. 721-734.

Tropp, Kristiina \& Saat, Helve 2010. Õpilaste suhted eakaaslaste ning täiskasvanutega ja sotsiaalsete oskuste areng. [Schoolchildren's Relationships with their Peers and Adults and Evolution of Social Skills.] In: Eve Kikas (ed.) Õppimine ja õpetamine esimeses ja teises kooliastmes. Tartu: Haridus- ja Teadusministeerium, pp. 61-89.

Vahtramäe, Ell 1998. Taevakirjad Siberi eesti asundustes. [Letters from Heaven in Estonian Settlements in Siberia.] In: Eesti kultuur võorrsil: Loode-Venemaa ja Siberi asundused. Tartu: Eesti Kirjandusmuuseum, pp. 180-194.

Valk, Aune 2003. Identiteet. [Identity.] In: Jüri Allik \& Anu Realo \& Kenn Konstabel (eds.) Isiksusepsühholoogia. Tartu: Tartu Ülikooli Kirjastus, pp. 225-250.

Valk, Aune \& Ojamaa, Triinu 2011. Identiteedist ja selle muutumisest väliseesti ühiskonnas. [Identity Processes in Diaspora Community.] Rahvuslik Kontakt 4 (212), pp. 21-27.

VanArsdale, Daniel 2007. Chain Letter Evolution. Available at http://www.silcom. com/ barnowl/chain-letter/evolution.html, last accessed on April 3, 2013.

Vignoles, Vivian L. \& Regalia, Camillo \& Manzi, Claudia \& Golledge, Jen \& Scabini, Eugenia 2006. Beyond self-esteem: influence of multiple motives on identity 
construction. Journal of Personality and Social Psychology 90 (2), pp. 308-333, doi:10.1037/0022-3514.90.2.308.

Voolaid, Piret 2012. Pane like ja postita oma seinale: Valimik Facebooki ahelpostitusi. [Click Like and Post it on Your Wall: Collection of Facebook Chain Posts.] Tallinn: Ajakirjade Kirjastus.

Voolaid, Piret \& Tuisk, Astrid \& Tupits, Ave 2007. Koolipärimus Eestis - viisteist aastat hiljem. [School Lore in Estonia: Fifteen Years Later.] In: Paar sammukest: Eesti Kirjandusmuuseumi aastaraamat 23. Tartu: Eesti Kirjandusmuuseumi Teaduskirjastus, pp. 353-362. 